Article

\title{
Do the Social Responsibility Efforts of the Destination Affect the Loyalty of Tourists?
}

\author{
Cheon Yu ${ }^{1}$ and Yun Seop Hwang ${ }^{2, *}$ \\ 1 Trade Research Institute, Kyung Hee University, Seoul 02447, Korea; cheon.yu@khu.ac.kr \\ 2 Department of International Business and Trade, Kyung Hee University, Seoul 02447, Korea \\ * Correspondence: rusiahys@khu.ac.kr
}

Received: 5 March 2019; Accepted: 2 April 2019; Published: 4 April 2019

\begin{abstract}
Tourist loyalty is one of the most crucial aspects in determining the sustainable growth of a tourism destination. In attempting to find an aspect that boosts tourist loyalty for sustainable development of a tourism destination, the role of destination social responsibility (DSR) has begun to attract the attention of researchers and tourism stakeholders. This study empirically examines the structural relationship between DSR, destination image, and tourist loyalty using data collected from international tourists who have visited Hoi An in Vietnam through a self-administrated survey. Also, this study takes the cultural differences between Asians and Westerners into consideration regarding insights on tourism marketing. The results show that the socially responsible behavior of a tourism destination positively affects tourist loyalty by forming a positive image of the destination. And the results of the comparison between the Asian and the Western groups on the structural relationships of the perceived DSR, destination image, and tourist loyalty show that different cultures afford different degrees of importance to the components of DSR.
\end{abstract}

Keywords: cultural difference; destination social responsibility; destination image; tourist loyalty

\section{Introduction}

Tourist loyalty is regarded as one of the most crucial aspects in determining the sustainable growth of a tourism destination. Tourists with loyalty towards destinations are not only likely to revisit the destinations, but are also likely to recommend the places to their acquaintances, which ultimately helps tourism stakeholders for the destinations to reduce the marketing costs required to lure tourists $[1,2]$. This is even more so the case for potential tourists who are expected to choose tourism destinations by referring the recommendations of previous visitors. Therefore, it is likely that positive tourist experiences have a positive impact on providing a positive image for a tourism destination and the revisit and referral intentions of tourists [3,4].

While there have been efforts to find an aspect that boosts tourist loyalty for sustainable development of a tourism destination, the role of social responsibility has begun to attract the attention of researchers and tourism stakeholders. Tourists' assessment of the social responsibility of the destination affects tourists' perception toward destinations [5-7]. The level of social responsibility of destinations affects tourists' choice of places for tourism because they are concerned about their own well-being. For instance, when destinations do not satisfy tourists' expectations because of polluted seas, burnt and chopped down forests, and litter-filled streets, tourists probably have negative impressions and negative images of those destinations. In other words, a high level of social responsibility for destinations can help visitors create a positive image of the destinations by providing them with well-preserved natural, historical, and cultural heritage. The positive image of the destinations is also created through tourists' satisfaction with their ethical consumption while at the destinations $[6,8]$. 
There has subsequently been a growing research trend and emerging literature on destination social responsibility (hereafter DSR; e.g., [9-11]). DSR, which is the collective concept and efforts of destination stakeholders to take social responsibilities, is defined by the perception of tourists $[9,10]$. Even so, it is hard to find empirical research on the impact of DSR on tourists' behaviors. For example, $\mathrm{Su}$ et al. [12] and Su and Swanson [10] conducted an empirical analysis to determine the effect of DSR on the environmentally responsible behavior of tourists. However, to the best of our knowledge, no research has yet been conducted to investigate the possible relationships between DSR, destination image, and tourist loyalty. In addition to this gap, the current literature on DSR has measured this construct within a single dimension even though DSR is conceptually comprised of different subcomponents including environmental, economic, ethical, and philanthropic aspects. Therefore, in this article, we empirically examine the structural relationship between DSR, destination image, and tourist loyalty while measuring DSR in a multi-dimensional way. To this end, the data were collected from international tourists who have visited Hoi An in Vietnam using a self-administrated survey.

In addition, the international tourism industry is continuing to grow steadily, and the rapid economic development of many Asian countries has served as a catalyst to increase Asian tourists' demand for international travel. Asian tourists most certainly have a different cultural background from the Western tourists that have been chiefly discussed in previous literature. Thus, it is necessary to take these cultural differences into consideration in order to gain further insights into tourism marketing because different cultural backgrounds imply that people have different values and beliefs. Consequently, differences in personal values and beliefs may create differences in travel preferences towards the same or similar tourism destinations provided that the values are defined as a way of thinking about the world, orienting oneself to it, and governing the specific behavioral choices of people [13]. Also, it should be noted that the concept of social responsibility was introduced first in Western cultures. Ergo, Asian tourists would have different perceptions and behaviors with regard DSR. Therefore, the cultural differences between Asian and Western tourists are predicted to provide a better understanding on tourist behaviors.

This paper is organized into the following sections: Following the introduction, Section 2 presents theoretical backgrounds and a review of current literature on DSR, destination image, tourist loyalty, and the impact of cultural differences. Section 3 demonstrates a conceptual model and delineates methods in detail. Section 4 assesses the measurement model and shows the test results for the hypotheses developed in Section 3. Finally, Section 5 contains discussion on the results, managerial implications, limitations, and research avenues for future research.

\section{Theoretical Background and Hypotheses}

\subsection{DSR for Sustainable Development}

Sustainable development in tourism has become more important due to an uptick in environmental damage, climate change, a depletion of natural resources, human rights issues, fair trade, and over-tourism. Sustainable development is defined as a process that meets the needs of the present generation without jeopardizing the ability of future generations to meet their own needs [14]. To achieve this goal, multiple aspects must be considered when developing tourism destinations including economic, political, socio-cultural, and ecological. The World Tourism Organization has provided the following guidelines for sustainable tourism development. First, sustainable tourism should be based on the optimal use of the environmental resources, such as maintaining essential ecological processes and helping to conserve natural heritage and biodiversity, which comprise key elements in tourism development. Second, sustainable tourism should respect the socio-cultural legitimacy of the involved communities, conserve all aspects of their cultural heritage and traditional values, and contribute to inter-cultural understanding and tolerance. Finally, sustainable tourism should ensure feasible long-term economic operations while also providing fairly distributed socio-economic benefits to all stakeholders, including stable employment, income-earning opportunities, and social services 
to host communities, as well as contributing to poverty alleviation [6]. In addition, a high level of dependence on natural, social, and cultural resources of the destination promotes the necessity of responsible tourism management in the tourism industry [15].

Su et al. [9] proposed the concept of DSR as an extension of the existing CSR in tourism. DSR is defined as the collective ideology and efforts of destination stakeholders to conduct socially responsible activities and it is perceived by not only local residents, but also tourists $[9,10,12]$. In this sense, DSR is regarded as the obligation to protect and improve the social and organizational interests of the entire destination, which applies to all stakeholders including tourists, community residents, industry, and governments [16]. DSR emphasizes the importance of responsible efforts of all involved stakeholders to build tourist destinations in a sustainable manner. In light of the definition of DSR, it is obvious that DSR should be jointly supported by not only the public and the private sectors involved in a destination, but also the tourists [10,11]. If DSR is not preferred by tourists, it will weaken the motive of DSR, and destination sustainability will be difficult to achieve. This assumption implies the need to identify the impact of DSR on tourists' perceptions and behaviors.

Research on the response of tourists to DSR is now in its early stages. Su and Swanson [10] identified that DSR increases tourists' positive emotions and at the same time reduces their negative ones. Also, they suggested that DSR ultimately has a positive impact on tourists' environmentally responsible behavior. Su et al. [12] investigated the impact of DSR perception on the intention of tourists to revisit a destination and recommend the place to their acquaintances and found that DSR is positively associated with both revisit and referral intentions. According to the study by Tran et al. [11], DSR has shown a positive effect on tourists' satisfaction through a mediating effect on their emotions.

\subsection{The Impacts of DSR on Destination Image and Tourist Loyalty}

Like any other consumer product, not only is a tourism destination a package of tourism facilities and services, but it is also composed of a number of attributes [17] and consists of an amalgam of products and services that are available in one location and are capable of drawing visitors to where it spatially confines them [18]. Hence, a destination can shape the tourists' perception and attitude with various demographic, natural, technological, political and cultural aspects $[19,20]$. Baloglu and McCleary [21] presented a general framework of destination image formation, suggesting that a destination's image is formed by both stimulus and personal aspects. Variables of the stimulus aspects include information sources, previous experiences, and distribution. The examples of personal aspects are tourists' social and psychological aspects such as value, motivations, personality, age, education, and so forth.

While focusing their perspective on the entire destination, Su et al. [9] proposed DSR based on prior CSR studies in the tourism industry. Thus, DSR is the collective activities of all the relevant stakeholders in the destination to minimize negative effects in terms of economy, environment, and social culture and to maximize benefits with which the destinations provide tourists. The entirety of these efforts are delivered to tourists and have an influence on tourists' experiences through tourism programs, attractions, accommodations, operating staff, and overall atmosphere. From this point of view, DSR is seen as one of the fundamental stimuli, forming a destinations image.

The evaluation of DSR by tourists affects their perceptions toward their destination in a variety of ways [6]. First, tourists may feel anxious about their well-being being undermined. Tourists are not only likely to avoid polluted tourism destinations, but also likely to consider the level of crime, incidences of locality, noise pollution, etc. Therefore, tourists who recognize a destination as a place with a high level of DSR will certainly have a positive image of it. In addition, a high level of DSR implies that destinations have well preserved natural, historical, and cultural tourist attractions. Different attractions will provide tourists with a variety of experiences, which is something that is difficult for tourists to feel in daily life. In the end, these versatile experiences will bring them a positive image of the tourism destination. Furthermore, it is noteworthy that some tourists want to avoid any situation in which their activities at the tourism destination have a negative impact on 
the area. In cases such as this, these tourists' perceptions toward DSR can minimize the potential of negative impact and will create a positive image of the tourism destination. Finally, tourists who positively perceive a tourism destination are more likely to revisit there or recommend it to their neighbors. As a consequence, there will be a positive relationship between destination image and tourist loyalty [22-24].

This study borrows the stimulus-organism-response (S-O-R) framework proposed by Mehrabian and Russell [25] to explain the relationship between DSR (S), destination image (O), and tourist loyalty (R) [10]. Therefore, this study sets destination image as a mediator, explaining the mechanism of how DSR affects tourist loyalty [26]. The tourists' perceived DSR is a cognitive antecedent of the tourists' destination image and this image ultimately affects tourist loyalty [12,27].

The definition of tourism destination image varies slightly among scholars [28]. Hunt [29] defined tourism destination image as "impressions that a person or persons hold about a state in which they do not reside" and Crompton [30] defined it as "the sum of the beliefs, ideas, and impressions that a person has of a destination". Similarly, Kim and Richardson [31] defined it as "a totality of impressions, beliefs, ideas, expectations, and feelings accumulated toward a place over time". Sahin and Baloglu [32] saw it as "the perception of a person or a group of people regarding a place". Despite these subtle differences, the majority of previous studies agreed that destination image is one of the main aspects in determining the success of destination management, marketing, and branding [33] since the image perceived by tourists plays a crucial role not only in pre-visit behaviors but also post-visit behaviors [21,34-37].

When tourists make a decision regarding the travel options, the destination image that people have toward a specific destination is directly associated with other aspects such as motivations, interests, cultural background, emotional state, and self-image [35]. Hence, decision-making regarding travel is based on perceptions rather than rational and logical judgment [38,39]. In other words, tourists often choose destinations based on awareness of information rather than what the information is [40]. As such, it is necessary for destinations to create positive images for tourists for successful marketing. In this sense, Echtner and Ritchie [33] insisted a destination must differentiate itself from its competitors in an advantageous manner or increase their positive mindshare. Every place has a specific image that plays an important role in attracting tourists [41].

In tourism literature, several researchers have regarded destination image as a multidimensional composition, with the two main dimensions being cognitive and affective [42-44]. The cognitive component refers to the beliefs and the knowledge held by tourists regarding a destination's attributes [45] and the affective component is defined by their feelings or emotional responses [46]. From a theoretical point of view, there is a general agreement that the cognitive component is an antecedent of the affective component [47-51]. For instance, Lin et al. [48] demonstrated that tourists develop feelings about a destination only after they cognitively evaluate it. Based on the discussions above, we can formulate the following hypotheses:

H1. The perception of DSR has a positive impact on cognitive destination image.

H2. The perception of DSR has a positive impact on affective destination image.

H3. Cognitive destination image is positively associated with affective destination image.

\subsection{Destination Image and Tourist Loyalty}

Tourist loyalty has been treated as an extension of customer loyalty in a tourism setting [52,53]. Given that destination experience is treated as a product, tourists decided to revisit or recommend the destination to friends and relatives after they travel to the destination $[1,54]$. Tourist loyalty has been conceptualized through the following approaches: behavioral loyalty (e.g., sequence purchase, proportion of patronage, or probability of purchase), attitudinal loyalty, and composite loyalty [55]. Yoon and Uysal [54] argued that the behavioral approach may not be enough to explain why and 
how they are willing to revisit or recommend destinations to other potential tourists. Attitudinal loyalty refers to tourists' psychological expressions of things such as intention to revisit a destination or recommend it to other potential tourists. In addition, Yoon and Uysal [54] also argued that the composite approach has limitations in that not all the weighting or quantified scores may apply to both the behavioral and attitudinal aspects, as they may have differing measurements. For the reasons above, in this study, we adopted the attitudinal approach for tourist loyalty, which refers to tourists' psychological expressions of things such as intention to revisit a destination or recommend it to other potential tourists $[1,36]$.

Although many studies have identified image as an antecedent of loyalty, mixed findings on the direction of the relationship have been found [46]. Thus, it is imperative to establish the relationship between destination image and tourist loyalty. Previous studies have found that positive correlations exist between tourist loyalty and image components including cognitive image and affective image. For the relationship between cognitive image and tourist loyalty, McDowall and Ma [24] demonstrated that cognitive image has a significant impact on tourists' intention to recommend. Some researchers obtained results showing that there are statistically significant relationships between both cognitive and affective image evaluations and intention to recommend $[51,56]$. When it comes to the relationship between affective image and tourist loyalty, Lee et al. [23] discovered that tourists with higher emotional attachment to South Korea were more likely to recommend the destination to others. Li et al. [49] demonstrated a direct relationship between the affective image and behavioral intentions. Kim and Malek [44] revealed the empirical result that tourist loyalty was positively influenced by affective destination image. Therefore, it is expected that the more positive the image of a destination held by a tourist, the greater the likelihood that he or she would recommend it to other potential tourists such as friends and relatives [36]. Based on the above arguments and empirical findings, we posit the following hypotheses:

H4. Cognitive destination image has a positive impact on tourist loyalty.

H5. Affective destination image has a positive impact on tourist loyalty.

\subsection{The Role of Cultural Differences in Tourist Perception}

The perception of tourists varies depending on cultural differences $[57,58]$. Tourists from different countries place emphasis on varying aspects of services offered at the destination, and it is likely that they have different levels of satisfaction, even if experiencing the same service $[57,59,60]$. Therefore, understanding the tourists' cultural backgrounds will help destinations design culture-oriented marketing and services [61-63]. There have been many studies examining differences in tourist perceptions and behaviors due to cultural differences [64]. Tourism motivations vary based on these cultural differences. You et al. [65] identified the difference between Japanese and U.K tourists using Dann's push-and-pull theory. In an experimental study conducted by Levy [66], the overall satisfaction, word-of-mouth referrals, and the intention to repeat a visit also vary between Asians and Westerners. Tsang and Ap [67] identified the differences in relational quality experiences between Asian and Western tourists using Hofstede's study. In a study by Kim and Malek [44], the relationship between the destination image and the tourist loyalty in Asian tourists were stronger than that of their Western tourists. However, the relationship that was apparent between the self-congruity and tourist loyalty was reversed. This is attributed to the preferences inherent between individualistic and collectivist cultures. In other words, Western tourists belong to a more individualistic culture, so they are more likely to be satisfied and loyal when they are allowed to do things themselves. Choi and Chu [68] also found that Asian and Western tourists place different importance levels on hotel service items. Asian tourists generally consider value for money to be the most important, while Western tourists consider it to be the room quality as the most important aspect. The hotel facilities also play a part in hotel satisfaction, with different amenities being valued based on different cultural demands [69]. In addition, there are also notable differences in services, brand personality perceptions, visit intentions, 
tourist satisfaction, tourist behaviors, etc., in terms of their cultural backgrounds $[57,64,68,70,71]$. DSR is defined as the collective activities of destination stakeholders to conduct socially responsible tourism $[10,11]$. The perception of what is DSR can vary depending on their culture. Different cultures show different degrees of importance on various components of DSR. These differences cause differences in the relationship between the destination image and tourist loyalty. Hence the hypothesis is as follows:

H6. The relationships among DSR, destination image, and tourist loyalty are different between Asian tourists and Western tourists.

\section{Research Design}

\subsection{Conceptual Model}

The conceptual model is presented in Figure 1. Here, DSR is categorized into five dimensional concepts based around findings from prior CSR studies (e.g., [72,73]). Each of these dimensions is predicted to have a direct positive correlation with destination image except tourist loyalty, which has an indirect relationship with DSR via destination image. Destination image consists of cognitive and affective dimensions and each of them is also expected to have a positive correlation with tourist loyalty, along with cognitive image being positively associated with affective image. Since we posit that the relationship among DSR, destination image, and tourist loyalty will be different between them, cultural difference will be measure for both Asian and Western cultures separately.

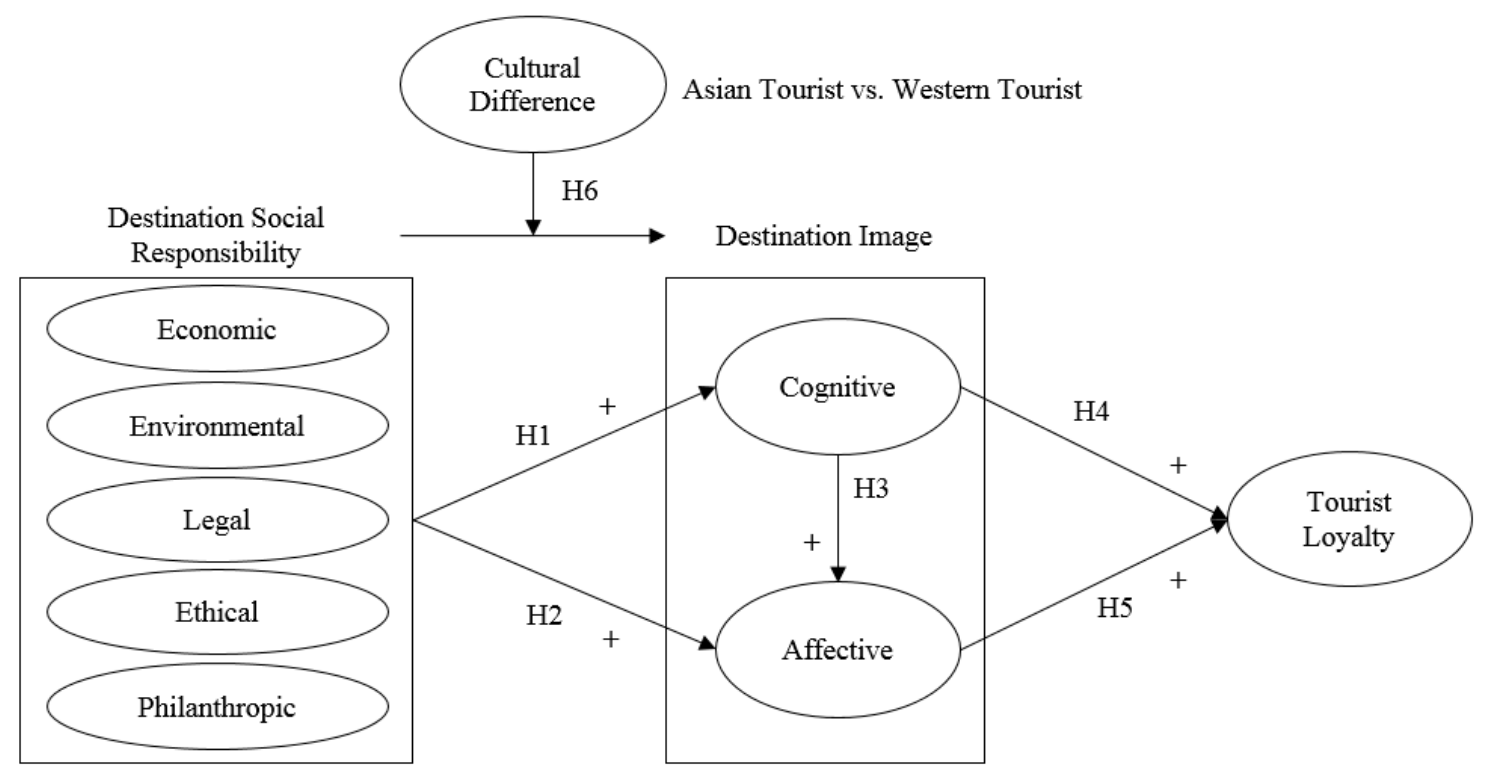

Figure 1. Conceptual Model.

\subsection{Operational Definition and Measurement}

Constructs employed in this study were assessed through multiple items on a 5-point Likert scale ranging from strongly disagree (1) to strongly agree (5). DSR, as suggested by previous studies, remains comprised of economic, environmental, legal, ethical, and philanthropic responsibilities [1012,72,74-76]. Economic responsibility and environmental were measured through seven items, legal responsibility, and philanthropic responsibility through four items, and ethical responsibility through six items. And in keeping with the information available in previous studies, six items were used to measure the cognitive destination image and three were used to measure affective destination image $[21,47,77,78]$. Tourist loyalty was measured though five items based on Zhang et al. [36]. The lists of all constructs and measurement items are shown in Table 1. 
Table 1. Measurement Items.

\begin{tabular}{|c|c|c|}
\hline Constructs & Measurement items & References \\
\hline $\begin{array}{c}\text { Economic } \\
\text { Responsibility }\end{array}$ & $\begin{array}{l}\text { "I thought that local authority, service providers and companies in Hoi An..." } \\
\text { 1. Tried to generate tourism profits. } \\
\text { 2. Improved the quality of their services and products. } \\
\text { 3. Made contributions to the national and local economy through } \\
\text { their businesses. } \\
\text { 4. Tried to generate employment through their operations. } \\
\text { 6. } \quad \text { Tried to attract more tourists. } \\
\text { 7. } \\
\end{array}$ & {$[11,79]$} \\
\hline $\begin{array}{l}\text { Environmental } \\
\text { Responsibility }\end{array}$ & $\begin{array}{l}\text { 1. Were concerned with protecting the environment. } \\
\text { 2. Used energy efficiently to protect the environment. } \\
\text { 3. Recycled waste. } \\
\text { 4. Used environmentally friendly products. } \\
\text { 5. Offered environment-friendly products and travel programs. } \\
\text { 6. Encouraged tourists to be environmentally friendly. } \\
\text { 7. Communicated to tourists about their environmental practices. }\end{array}$ & {$[11,74,79]$} \\
\hline $\begin{array}{c}\text { Legal } \\
\text { Responsibility }\end{array}$ & $\begin{array}{l}\text { 1. Protected consumers and took responsibility for their products/services. } \\
\text { 2. Resolved service problems promptly. } \\
\text { 3. Observed legal responsibility and standards. } \\
\text { 4. Treated customers honestly and ethically. }\end{array}$ & {$[11,80]$} \\
\hline $\begin{array}{c}\text { Ethical } \\
\text { Responsibility }\end{array}$ & $\begin{array}{l}\text { 1. Did not practice exaggerated and false advertisements. } \\
\text { 2. Provided full and accurate information about products / services } \\
\text { 3. He customers. } \\
\text { 4. Established ethical guidelines for business activities. } \\
\text { 5. Tried to become ethically trustworthy service providers. } \\
\text { 6. Provided a healthy and safe working environment for employees. }\end{array}$ & {$[11,75]$} \\
\hline $\begin{array}{l}\text { Philanthropic } \\
\text { Responsibility }\end{array}$ & $\begin{array}{l}\text { 1. Did charity activities. } \\
\text { 2. Played a role in society that goes beyond mere profit generation. } \\
\text { 3. Tried to fulfill their social responsibility. } \\
\text { 4. }\end{array}$ & {$[11,81,82]$} \\
\hline $\begin{array}{l}\text { Cognitive } \\
\text { Image }\end{array}$ & $\begin{array}{l}\text { 1. Hoi An has beautiful scenery. } \\
\text { 2. Natural Environment is attractive } \\
\text { 3. Hoi An has unique environmental characteristics } \\
\text { 4. Hoi An has an atmosphere conducive to relaxation and rest } \\
\text { 5. Hoi An has unique historic/cultural heritage sites } \\
\text { 6. Hoi An has unique traditional architecture. }\end{array}$ & {$[21,47,77,78]$} \\
\hline Affective Image & $\begin{array}{l}\text { "Through experience in Hoi An, ..." } \\
\text { 1. I felt happy. } \\
\text { 2. I felt relaxed. } \\
\text { 3. I felt excited. }\end{array}$ & \\
\hline Tourist Loyalty & $\begin{array}{l}\text { 1. If I had to decide again, I would choose Hoi An } \\
\text { 2. I will revisit Hoi An. } \\
\text { 3. I will encourage friends and relatives to visit Hoi An } \\
\text { 4. I will recommend Hoi An to friends and relatives. } \\
\text { 5. I will say positive things about Hoi An to other people }\end{array}$ & [36] \\
\hline
\end{tabular}

\subsection{Method and Study Site}

To explore the relationship between DSR, destination image, and tourist loyalty, this study employs a structural equation model (SEM). SEM models are useful for dealing with latent constructs and complex models, analyzing direct, indirect and total effects, and assessing structural models [83]. SEM is generally divided into two differing approaches [84]: The first is the covariance-based SEM (CB-SEM) used primarily for theoretical verification, and the second is the partial least square SEM (PLS-SEM) used in exploratory studies. CB-SEM estimates causal relationships based on the maximum likelihood (ML) estimation process, which combines both confirmation factor and path analysis. 
PLS-SEM uses a regression-based address squares test method and a model that combines exploratory factor analysis and path analysis [85]. This study adopts PLS-SEM via the SmartPLS v3.2.7 program developed by SmartPLS GmbH in Bönningstedt, Germany, which has been widely employed in recent tourism research $[86,87]$. This is due to the fact that DSR is a relatively modern concept and lacks empirical data on its various subcomponents. Previous studies on DSR (e.g., $[9,10,12])$ all measured DSR in one single dimension. The methodology used here is far more appropriate, especially considering that PLS-SEM focuses on explaining the latent constructs' variance through minimizing the error term and maximizing the R-squared $\left(R^{2}\right)$ values of a model to identify possible relationships between constructs. In addition, PLS multi-group analysis was conducted to identify the impact of DSR while taking into account the cultural differences between Asian and Western tourists. Unlike CB-SEM, PLS-SEM does not focus on accounting for measurement item covariance [88]. Consequently, the hypotheses are tested based on the structural model only after evaluating the measurement model.

This study was carried out in Hoi An, one of the most famous destinations for foreign tourists in Vietnam. The climate in Hoi An is rather mild with an annual average temperature is $25.6^{\circ} \mathrm{C}$. Humidity averages $82 \%$, rainfall reaches up to $2066 \mathrm{~mm}$ and there are 2158 hours of sunshine per year. Hoi An has a size of 6027.25 ha and the total population is around 83,000. It has more than 2000 years of history and has been developed relatively recently, so it preserves its unique cultural heritage and natural resources as a tourism destination. With its reputation for natural beauty and cultural uniqueness, Hoi An was recognized as a World Heritage Site by UNESCO in 1999. Since then, the number of international tourists visiting Hoi An has increased sharply from 73,457 to 608,477 in 2007 [89]. According to the government, in 2017, Hoi An welcomed 1.78 million tourists. The rapid development of the Hoi An tourism industry has had both positive effects, such as increased income and job creation, as well as negative effects, such as increased prices, estrangement of local residents, traffic congestion, noise, and air pollution [89]. To protect the heritage and the natural resources from such problems, the Hoi An government established strict regulations and guidelines that all stakeholders are required to follow. For example, there are regulations on the management of traditional houses and buildings, a prohibition of the use of plastic bags, and ongoing recommendations for eco-friendly transportation, such as bicycles and electric vehicles, etc., which have all been enacted. Additionally, tourism operators and local communities are actively participating in these social responsibilities. From this point of view, Hoi An is a very suitable destination for studying the impacts of DSR on destination image and tourist loyalty [90].

The data used in this study were collected from international tourists visiting Hoi An in Vietnam through a self-administrated questionnaire. The convenience sampling method was used, and the survey period was from August 23 to September 8, 2017. The researchers briefly explained the purpose of the study to the survey respondents and asked for their participation. A total of 371 questionnaires were collected and 359 valid responses were analyzed. Within the profiles of the respondents, $50.4 \%$ were male, and $67.7 \%$ were aged between 20 and 39. The percentage with a college degree or higher was $85.5 \%$ and $59.9 \%$ answered that their annual income level was higher than USD $\$ 50,000$. The respondents' nationalities had the following distribution: 44.3\% European, 34.5\% Asian, and 13.6\% Australian. Lastly, $84 \%$ of the tourists visited Hoi An for the first time, $98 \%$ visited for leisure purposes, $92 \%$ were accompanied by friends or family, and $94 \%$ stayed 7 days or less.

\section{Results}

\subsection{Measurement Model Evaluation}

To ensure the appropriateness of the research instrument, we examined convergent validity, internal consistency reliability, and discriminant validity before the researchers tested the hypotheses. Convergent validity was verified using an outer loading relevance, an average barrier extraction, and an indicator reliability. Internal consistency reliability was verified using composite reliability (CR), 
Cronbach's $\alpha$, Dijkstra-Hensler's rho_A. And the heterotrait-monotrait ratio (HTMT) was used to verify discriminant validity.

The following are the results from testing the measurement model. Initially, the outer of loading relevance of the seventh item of the economic responsibility measurement, the third and fourth items of the legal responsibility measurement items, the second item of the environmental responsibility measurement, and the fifth item of ethical responsibility measurement we found to be lower than the acceptance criterion (>0.7) [91]. And the HTMT of legal responsibility and ethical responsibility contained more than 1.0, indicating that it did not have discriminant validity. This study removed the low-loading items of economic, environmental, legal, and ethical responsibility and the two constructs, which did not secure discriminant validity, legal and ethical responsibility, in order to ensure the appropriateness of the empirical model. In the re-test of the measurement model evaluation, all of the criteria were met. In this study, the results of the first measurement model evaluation are presented in Tables 2 and 3 illustrates the correlations between latent variables. The top correlation was 0.483 , between philanthropic responsibility and tourist loyalty, indicating that there is no multicollinearity.

Table 2. Summary of the first measurement model evaluation.

\begin{tabular}{|c|c|c|c|c|c|c|c|c|}
\hline \multirow{3}{*}{ Constructs } & \multirow{3}{*}{ Items } & \multicolumn{3}{|c|}{ Convergent Validity } & \multicolumn{3}{|c|}{ Internal Consistency Reliability } & \multirow{2}{*}{$\begin{array}{c}\text { Discriminant } \\
\text { HTMT }\end{array}$} \\
\hline & & $\begin{array}{l}\text { Outer Loading } \\
\text { Relevance }\end{array}$ & $\begin{array}{c}\text { Indicator } \\
\text { Reliability }\end{array}$ & AVE & Cronbach' $\alpha$ & $\begin{array}{c}\text { rho_A } \\
(\rho \mathbf{A})\end{array}$ & CR & \\
\hline & & $>0.70$ & $>0.50$ & $>0.50$ & $0.60 \sim 0.90$ & $>0.70$ & $0.60 \sim 0.90$ & $>1.0$ \\
\hline \multirow{7}{*}{ Economic } & Economic 1 & 0.858 & 0.736 & \multirow{7}{*}{0.681} & \multirow{7}{*}{0.896} & \multirow{7}{*}{0.949} & \multirow{7}{*}{0.929} & \multirow{7}{*}{ Secure } \\
\hline & Economic 2 & 0.881 & 0.776 & & & & & \\
\hline & Economic 3 & 0.908 & 0.824 & & & & & \\
\hline & Economic 4 & 0.897 & 0.805 & & & & & \\
\hline & Economic 5 & 0.888 & 0.789 & & & & & \\
\hline & Economic 6 & 0.914 & 0.835 & & & & & \\
\hline & Economic 7 & 0.066 & 0.004 & & & & & \\
\hline \multirow{7}{*}{ Environmental } & Environment 1 & 0.779 & 0.607 & \multirow{7}{*}{0.549} & \multirow{7}{*}{0.836} & \multirow{7}{*}{0.888} & \multirow{7}{*}{0.884} & \multirow{7}{*}{ Secure } \\
\hline & Environment 2 & 0.117 & 0.014 & & & & & \\
\hline & Environment 3 & 0.787 & 0.619 & & & & & \\
\hline & Environment 4 & 0.789 & 0.623 & & & & & \\
\hline & Environment 5 & 0.785 & 0.616 & & & & & \\
\hline & Environment 6 & 0.822 & 0.676 & & & & & \\
\hline & Environment 7 & 0.830 & 0.689 & & & & & \\
\hline \multirow{4}{*}{ Legal } & Legal 1 & 0.876 & 0.767 & \multirow{4}{*}{0.410} & \multirow{4}{*}{0.294} & \multirow{4}{*}{0.783} & \multirow{4}{*}{0.563} & \\
\hline & Legal 2 & 0.916 & 0.839 & & & & & \\
\hline & Legal 3 & 0.104 & 0.011 & & & & & Not Secure \\
\hline & Legal 4 & -0.154 & 0.024 & & & & & \\
\hline & Ethical 1 & 0.865 & 0.748 & & & & & \\
\hline & Ethical 2 & 0.887 & 0.787 & & & & & \\
\hline & Ethical 3 & 0.829 & 0.687 & & & & & \\
\hline Ethical & Ethical 4 & 0.899 & 0.808 & 0.505 & 0.697 & 0.894 & 0.806 & Not Secure \\
\hline & Ethical 5 & 0.016 & 0.000 & & & & & \\
\hline & Ethical 6 & 0.017 & 0.000 & & & & & \\
\hline & Philanthropic 1 & 0.890 & 0.792 & & & & & \\
\hline & Philanthropic 2 & 0.907 & 0.823 & & & & & \\
\hline Philanthropic & Philanthropic 3 & 0.866 & 0.750 & 0.805 & 0.919 & 0.923 & 0.943 & Secure \\
\hline & Philanthropic 4 & 0.924 & 0.854 & & & & & \\
\hline & Cognitive 1 & 0.884 & 0.781 & & & & & \\
\hline & Cognitive 2 & 0.869 & 0.755 & & & & & \\
\hline Cognitive & Cognitive 3 & 0.877 & 0.769 & & & & & \\
\hline Image & Cognitive 4 & 0.923 & 0.852 & 0.769 & 0.939 & 0.940 & 0.952 & Secure \\
\hline & Cognitive 5 & 0.794 & 0.630 & & & & & \\
\hline & Cognitive 6 & 0.909 & 0.826 & & & & & \\
\hline & Affective 1 & 0.830 & 0.689 & & & & & \\
\hline Affective & Affective 2 & 0.914 & 0.835 & 0.755 & 0.837 & 0.846 & 0.902 & Secure \\
\hline Image & Affective 3 & 0.860 & 0.740 & & & & & \\
\hline & Loyalty 1 & 0.812 & 0.659 & & & & & \\
\hline & Loyalty 2 & 0.855 & 0.731 & & & & & \\
\hline Tourist Loyalty & Loyalty 3 & 0.792 & 0.627 & 0.719 & 0.902 & 0.905 & 0.927 & Secure \\
\hline & Loyalty 4 & 0.869 & 0.755 & & & & & \\
\hline & Loyalty 5 & 0.905 & 0.819 & & & & & \\
\hline
\end{tabular}


Table 3. Matrix of correlation between latent variables.

\begin{tabular}{ccccccc}
\hline & (A) & (B) & (C) & (D) & (E) & (F) \\
\hline Affective (A) & 1 & & & & & \\
Economic (B) & 0.371 & 1 & & & & \\
Environmental (C) & 0.308 & 0.374 & 1 & & & \\
Tourist Loyalty (D) & 0.313 & 0.179 & 0.201 & 1 & & \\
Cognitive (E) & 0.435 & 0.233 & 0.259 & 0.413 & 1 & 1 \\
Philanthropic (F) & 0.331 & 0.243 & 0.202 & 0.483 & 0.272 & \\
\hline
\end{tabular}

\subsection{Structural Model and Hypothesis 1 to5 Testing}

The structural model was evaluated using standardization path coefficients, their significance level, and $\mathrm{R}^{2}$ estimates. Figure 2 illustrates details on the parameter estimates for the model and $\mathrm{R}^{2}$. And Table 4 reports the results of hypothesis 1 to 5 tests. The $R^{2}$ s of cognitive image, tourist loyalty, and affective image are $0.129,0.192$, and 0.306 , respectively. This means that the exogenous variable of each construct explains $12.9 \%, 30.6 \%$, and $19.2 \%$ of each of the constructs. The $\mathrm{R}^{2}$ values are greater than the recommended value of 0.10 [92].

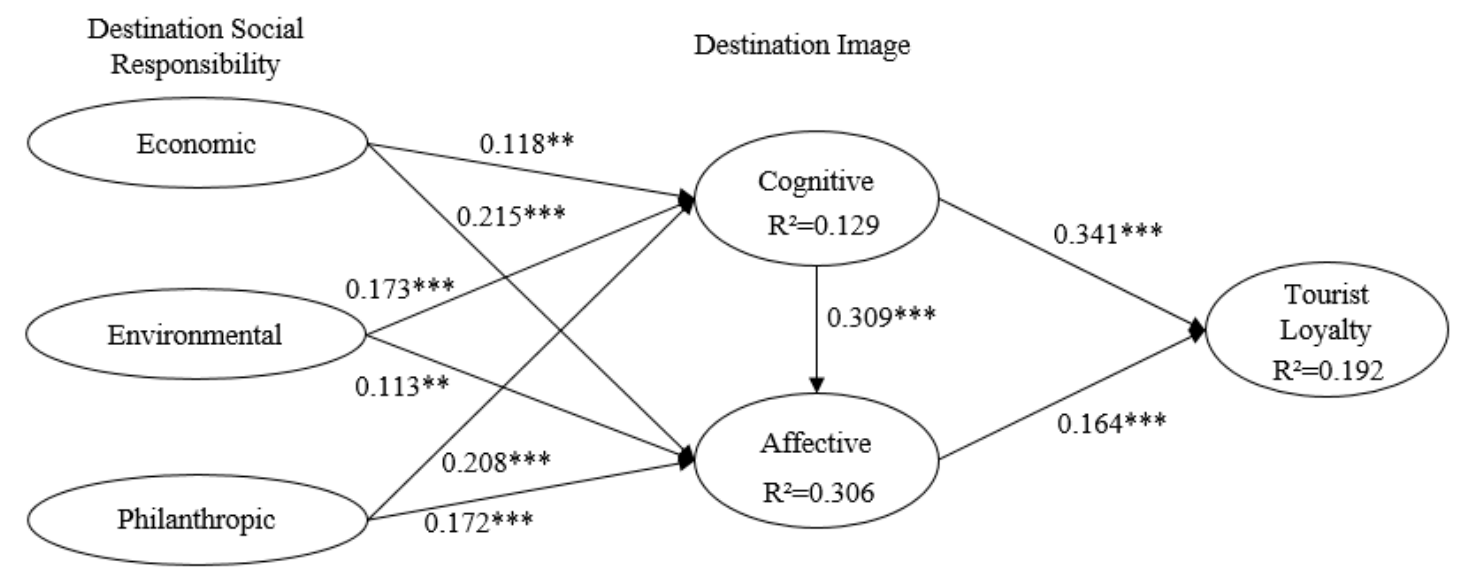

Note: ${ }^{* *} p$-value $<0.05,{ }^{* * *} p$-value $<0.01$.

Figure 2. Estimation of the structural model.

Table 4. Results of testing hypothesis 1 to 5 .

\begin{tabular}{clccc}
\hline & Hypothesis & Path Coefficient & $t$-value & Results \\
\hline \multirow{3}{*}{ H1 } & Economic $\rightarrow$ Cognitive & 0.118 & 2.070 & Supported \\
\cline { 2 - 5 } & Environmental $\rightarrow$ Cognitive & 0.173 & 3.271 & Supported \\
\cline { 2 - 5 } & Philanthropic $\rightarrow$ Cognitive & 0.208 & 3.705 & Supported \\
\hline \multirow{2}{*}{ H2 } & Economic $\rightarrow$ Affective & 0.215 & 4.053 & Supported \\
\cline { 2 - 5 } & Environmental $\rightarrow$ Affective & 0.113 & 2.329 & Supported \\
\cline { 2 - 5 } & Philanthropic $\rightarrow$ Affective & 0.172 & 2.982 & Supported \\
\hline H3 & Cognitive $\rightarrow$ Affective & 0.309 & 6.107 & Supported \\
\hline H4 & Cognitive $\rightarrow$ Tourist Loyalty & 0.341 & 6.031 & Supported \\
\hline H5 & Affective $\rightarrow$ Tourist Loyalty & 0.164 & 2.836 & Supported \\
\hline
\end{tabular}


All hypotheses from 1 to 5 are supported by the obtained data. H3 predicts that a cognitive destination image has a positive relationship with an affective destination image. The analysis result supports $H 3$ ( $\beta=0.309, t=6.107, p<0.01$ ). The more positive the cognitive image, the more positive the affective image that is subsequently formed. $\mathrm{H} 4$ and $\mathrm{H} 5$ predict that a high level of destination image has a positive effect on tourist loyalty and the results of the analysis support this $(\beta=0.341, t=6.031, p$ $<0.01 ; \beta=0.164, t=2.836, p<0.01$ ). Both the cognitive and the affective image of a destination have a positive correlation with tourist loyalty. H1 predicts that a high level of DSR has a positive relationship with a cognitive destination image. The analysis supports $\mathrm{H} 1$ because a positive and statistically significant relationship was found (economic responsibility, $\beta=0.118, \mathrm{t}=2.070, p<0.05$; environmental responsibility, $\beta=0.173, t=3.271, p<0.01$; philanthropic responsibility, $\beta=0.208, t=3.705, p<0.01$ ). The more positive the perceived DSR, the more positive the cognitive image that is formed for the destination. $\mathrm{H} 2$ predicts that a high level of DSR has a positive relationship with affective image. $\mathrm{H} 2$ is supported by the results because a positive and statistically significant relationship was determined (economic responsibility, $\beta=0.215, \mathrm{t}=4.053, p<0.01$; environmental responsibility, $\beta=0.113, \mathrm{t}=2.329$, $p<0.05$; philanthropic responsibility, $\beta=0.172, \mathrm{t}=2.982, p<0.01$ ). The more positive the perceived DSR, the more positive the affective image that is formed for the destination.

The total effects observed in the structural model are illustrated in Table 5. Every path showed statistically significant effects. Specifically, the philanthropic responsibility $(\beta=0.110, p<0.01)$ among the three responsibilities had the greatest effect on tourist loyalty. The economic $(\beta=0.081, p<0.01)$ and environmental $(\beta=0.086, p<0.01)$ responsibilities had a similar scale effect on tourist loyalty. The influence of philanthropic responsibility $(\beta=0.208, p<0.01)$ was the largest in the relationship between DSR and cognitive image, subsequently followed by environmental responsibility ( $\beta=0.173$, $p<0.01)$ and economic responsibility $(\beta=0.118, p<0.05)$. The influence of economic responsibility ( $\beta=0.251, p<0.01$ ) was greatest in the relationship between DSR and affective image, subsequently followed by the philanthropic $(\beta=0.236, p<0.01$ ) and the environmental responsibilities $(\beta=0.166$, $p<0.01)$. In the relationship between destination image and tourist loyalty, the cognitive component $(\beta=0.392, p<0.01)$ had a greater effect than the affective $(\beta=0.164, p<0.01)$.

Table 5. Direct, indirect, and total effects of the relationships.

\begin{tabular}{|c|c|c|c|}
\hline Pat & & & Total Effect (Indirect Effect) \\
\hline Economic Responsibility & \multirow{3}{*}{$\rightarrow$} & \multirow{3}{*}{ Tourist Loyalty } & $0.081^{* * *}$ \\
\hline Environmental Responsibility & & & $0.086^{* * *}$ \\
\hline Philanthropic Responsibility & & & $0.110^{* * *}$ \\
\hline Economic Responsibility & \multirow{3}{*}{$\rightarrow$} & \multirow{3}{*}{ Cognitive Image } & $0.118^{* *}$ \\
\hline Environmental Responsibility & & & $0.173^{* * *}$ \\
\hline Philanthropic Responsibility & & & $0.208^{* * *}$ \\
\hline Economic Responsibility & \multirow{3}{*}{$\rightarrow$} & \multirow{3}{*}{ Affective Image } & $0.251(0.036)^{* * *}$ \\
\hline Environmental Responsibility & & & $0.166(0.053)^{* * *}$ \\
\hline Philanthropic Responsibility & & & $0.236(0.064)^{* * *}$ \\
\hline Cognitive Image & \multirow{2}{*}{$\rightarrow$} & \multirow{2}{*}{ Tourist Loyalty } & $0.392(0.051)^{* * *}$ \\
\hline Affective Image & & & $0.164^{* * *}$ \\
\hline
\end{tabular}

\subsection{Hypothesis 6 Testing Cultural Difference}

H6 predicts that the relationships between DSR, destination image, and tourist loyalty are stronger for Asian tourists than Western tourists. Table 6 illustrates the results for H6, which only partially support it. Though it was statistically significant, only the economic responsibility and cognitive 
image relationship supported the hypothesis that Asian tourists had a stronger relationship than Western tourists. Specifically, while environmental responsibility and cognitive image showed a statistically significant relationship in both groups, but there was no difference in the coefficient value. The relationship between philanthropic responsibility and cognitive image, while significant in the Western group, was not the Asian group and there was no significant difference in the coefficient value between them. To much the same result, economic responsibility and affective image showed a statistically significant relationship in both groups, but also showed no difference in coefficient value. The pattern repeated as the correlation between environmental and philanthropic responsibilities and affective image were again significant in the Western group and not in the Asian group while showing no difference in the coefficient value. Also, while cognitive image and affective image showed a statistically significant relationship in both groups, again, there was no difference in the coefficient value. These same results were observed again with cognitive image and tourist loyalty showing a statistically significant relationship in both groups with no difference in the coefficient value. Affective image and tourist loyalty continued this trend.

Table 6. Comparison between Asian and Western tourists' groups.

\begin{tabular}{|c|c|c|c|c|}
\hline & & $\begin{array}{c}\text { Path Coefficient } \\
\text { (Asian) }\end{array}$ & $\begin{array}{l}\text { Path Coefficient } \\
\text { (Western) }\end{array}$ & $\begin{array}{c}\text { Difference } \\
\text { (Asian-Western) }\end{array}$ \\
\hline Economic & \multirow{3}{*}{$\rightarrow$ Cognitive } & $0.221^{* * *}$ & 0.063 & 0.158 * \\
\hline Environmental & & $0.253^{* * *}$ & 0.125 * & 0.128 \\
\hline Philanthropic & & 0.106 & $0.262^{* * *}$ & -0.157 \\
\hline Economic & \multirow{3}{*}{$\rightarrow$ Affective } & $0.256^{* *}$ & $0.197^{* * *}$ & 0.058 \\
\hline Environmental & & 0.145 & $0.111^{* *}$ & 0.034 \\
\hline Philanthropic & & 0.087 & $0.216^{* * *}$ & -0.129 \\
\hline Cognitive & $\rightarrow$ Affective & $0.277^{* * *}$ & $0.319^{* * *}$ & -0.042 \\
\hline Cognitive & \multirow{2}{*}{$\rightarrow$ Tourist Loyalty } & $0.410^{* * *}$ & $0.306^{* * *}$ & 0.104 \\
\hline Affective & & $0.195^{* *}$ & $0.153^{* *}$ & 0.041 \\
\hline
\end{tabular}

\section{Discussion and Conclusions}

The results of this study show that the socially responsible behavior of a tourism destination positively affects tourist loyalty by forming a positive image of the destination. The destination image is formed by stimuli including not only the variety of aspects presented by previous literature, but also the social responsibility of the tourism destination. DSR reflects the collective activities of all of the relevant stakeholders in a destination to maximize the positive benefits and minimize the negative effects in terms of economy, environment, and social culture. DSR can provide a well-defined tourism experience through the support of local residents and the preservation of natural, historical, and cultural places. It also provides visitors with ethical satisfaction, which means that they are spending on the right things $[9,22-24]$. Therefore, tourists visiting a destination with high DSR levels have a positive destination image and show loyalty through revisiting and referrals. In previous studies, DSR has been shown to have an impact on tourist satisfaction and increase tourist loyalty by mediating emotion [11,12]. This study examines the mechanism of DSR on tourist behaviors through exploring the role of destination image as a component of DSR.

DSR is found to be multidimensional and the impact of DSR on destination image differed. Most literature, except Tran et al. [11], on DSR measured this construct within a single dimension even though DSR is conceptually comprised of different components, including environmental, economic, ethical, and philanthropic aspects $[9,10,12,16]$. The multidimensionality of DSR plays an important role 
in managing tourism destinations because it can contribute to accurately conveying the identity of the destination to tourists. This study has originality as it contributes to identifying the multidimensionality of DSR.

The comparison between Asian and Western groups on the structural relationships of the perceived DSR, destination image, and tourist loyalty is another aspect of originality. The results show that different cultures apply different degrees of importance to each component of DSR. This study shows that economic and environmental responsibility have a significant positive impact on the cognitive image of a destination in the Asian tourist group, while environmental and philanthropic responsibility have a significant positive relationship with the Western tourist group. And, in the relationship between DSR and affective image, only economic responsibility has a significant positive impact in the Asian group while, in the Western group, all responsibilities have a significant positive impact. These differences are due to tourist self-congruency on DSR [93]. DSR is composed of the economic, environmental, and social-cultural responsibilities of a destination's stakeholders for tourism sustainability. According to the self-congruency theory, when the responsibility is in line with the self-concept of tourists, it contributes to the formation of a positive destination image and enhances the tourist loyalty [94]. This mechanism can be applied to each component of DSR. In other words, it responds differently to the social responsibility of the destination according to the cultural background of the tourists. Western culture is more individualistic than Asian culture, when DSR components are judged to be in line with themselves, a more positive destination image is formed and loyalty is enhanced $[44,65]$. As mentioned previously, the concept of CSR was first introduced in the West, which makes it possible to infer that Western tourists are more sensitive to DSR than Asians. The results for the Asian group show that only economic responsibility has a direct impact on the affective image of a destination. The reason is presumed to be due to the fact that the economies of Asian countries have been developed more recently, thereby placing greater emphasis on economic value. This discussion once again confirms that culture is one of the most important aspects of explaining international tourist behavior patterns and shows that cultural differences should be considered when developing tourism marketing strategies [95].

Based on data obtained from this research, several managerial implications can be suggested for the tourism industry. First, the introduction of DSR to tourism can contribute to the sustainable growth of a destination. This can be accomplished in two ways. One is the prevention of problems caused by excessive tourism development. For example, Boracay Island in the Philippines and Maya Bay Beach in Phi Phi Island in Thailand were recently closed due to environmental problems, which caused serious damage to the local tourism economy. If DSR had been applied to these destinations, it would have been possible to prevent this situation. The other implication stems from competitive advantage. DSR influences the formation of a positive destination image and promotes tourist loyalty. The introduction of DSR to a tourism destination not only makes a destination more attractive to tourists, but also contributes to the sustainable development of the local economy. Thus, adapting DSR can make a destination preferable to one that is over-developed while still helping with economic growth.

Lastly, the marketing for DSR should be divided between Western and Asian tourists. To positively shape the cognitive image for Asian tourists, economic and environmental responsibility must be emphasized. For affective image, economic responsibility should to be emphasized. Using these traits, it is possible to properly communicate to the target that a destination can provide a well-designed tourism service, program, and facilities, etc., which is what the tourists require. Also, it informs tourists that the services are operated in an environmentally friendly manner. To positively shape the cognitive image for Western tourists, the manager should emphasize environmental and philanthropic responsibility. This shows that the tourism destination is not only eco-friendly but also helpful to the local community. It is also helpful to advertise that DSR is comprehensively integrated into the overall operation in order to form a positive affective image for Western tourists.

Despite the implications listed above, there are limitations to the results obtained in this study. The most glaring is that, among the components of DSR, legal responsibility and ethical responsibility 
were not able to obtain a discriminant valuation. Also, in Tran et al. [11] using CB-SEM, unlike the researchers' expectations, DSR was found to be a component of four. This articulates the need for the present DSR measurement scale to be improved upon. As such, using CSR as a theory framework to measure DSR may not be completely suitable for all tourism destinations [11]. Also, this study explored the structural relationships of the specified areas in one particular place, Hoi An, Vietnam, which is a destination famous for its unique cultural heritage and natural resources. For better generalization regarding DSR, further empirical studies are needed at a greater variety of destinations.

Author Contributions: Conceptualization: C.Y. and Y.S.H.; Formal analysis: C.Y.; Project administration: Y.S.H.; Supervision: Y.S.H.; Writing original draft: C.Y.; Writing—-review and editing: Y.S.H.

Funding: This study received no external funding.

Acknowledgments: This work was supported by the Ministry of Education of Korea and the National Research Foundation of Korea (NRF-2016S1A5B6925462). We thank Hyunh Anh Thu Tran for allowing us to use the data for this article.

Conflicts of Interest: The authors declare no conflicts of interest.

\section{References}

1. Oppermann, M. Tourism destination loyalty. J. Travel Res. 2000, 39, 78-84. [CrossRef]

2. Reichheld, F.F. Loyalty-based management. Harv. Bus. Rev. 1993, 71, 64-73.

3. Bramwell, B. User satisfaction and product development in urban tourism. Tour. Manag. 1998, 19, 35-47. [CrossRef]

4. Ross, E.L.D.; Iso-Ahola, S.E. Sightseeing tourists' motivation and satisfaction. Ann. Tour. Res. 1991, 18, 226-237. [CrossRef]

5. Curtin, S. Wildlife tourism: The intangible, psychological benefits of human-wildlife encounters. Curr. Issues Tour. 2009, 12, 451-474. [CrossRef]

6. United Nations Environment Programme (UNEP). Making Tourism More Sustainable-A Guide for Policy Makers; UNEP and World Tourism Organization: Paris, France, 2005; ISBN 978-92-844-0821-4.

7. Zeppel, H.; Muloin, S. Conservation benefits of interpretation on marine wildlife tours. Hum. Dimens. Wildl. 2008, 13, 280-294. [CrossRef]

8. Hartman, S. Towards adaptive tourism areas? A complexity perspective to examine the conditions for adaptive capacity. J. Sustain. Tour. 2016, 24, 299-314. [CrossRef]

9. Su, L.; Huang, S.; Huang, J. Effects of destination social responsibility and tourism impacts on residents' support for tourism and perceived quality of life. J. Hosp. Tour. Res. 2018, 42, 1039-1057. [CrossRef]

10. Su, L.; Swanson, S.R. The effect of destination social responsibility on tourist environmentally responsible behavior: Compared analysis of first-time and repeat tourists. Tour. Manag. 2017, 60, 308-321. [CrossRef]

11. Tran, H.; Hwang, Y.; Yu, C.; Yoo, S. The Effect of Destination Social Responsibility on Tourists' Satisfaction: The Mediating Role of Emotions. Sustainability 2018, 10, 3044. [CrossRef]

12. Su, L.; Huang, S.S.; Pearce, J. How does destination social responsibility contribute to environmentally responsible behaviour? A destination resident perspective. J. Bus. Res. 2018, 86, 179-189. [CrossRef]

13. Lustig, M.W. Value differences in intercultural communication. In Intercultural Communication: A Reader, 5th ed.; Samovar, L.A., Porter, R.E., Eds.; Wadsworth Pub. Co.: Belmont, CA, USA, 1988; pp. 55-61. ISBN 100534085989.

14. United Nations World Commission on Environment and Development (WCED). Our Common Future; United Nations; Oxford University Press: Oxford, New York, USA, 1987.

15. Sheldon, P.J.; Park, S.Y. An exploratory study of corporate social responsibility in the US travel industry. J. Travel Res. 2011, 50, 392-407. [CrossRef]

16. Su, L.; Wang, L.; Law, R.; Chen, X.; Fong, D. Influences of destination social responsibility on the relationship quality with residents and destination economic performance. J. Travel Tour. Mark. 2017, 34, 488-502. [CrossRef]

17. Hu, Y.; Ritchie, J.B. Measuring destination attractiveness: A contextual approach. J. Travel Res. 1993, 32, 25-34. [CrossRef] 
18. Pearce, D.G. Tourist Development, 2nd ed.; Longman Scientific \& Technology: Harlow, UK, 1981; ISBN 100582300533.

19. Kotler, P.; Bowen, J.T.; Makens, J.C. Marketing for Hospitality and Tourism, 4th ed.; Prentice-Hall, Inc.: Upper Saddle River, NJ, USA, 2006; ISBN 100132017733.

20. Smith, S.L. The tourism product. Ann. Tour. Res. 1994, 21, 582-595. [CrossRef]

21. Baloglu, S.; McCleary, K.W. A model of destination image formation. Ann. Tour. Res. 1999, $26,868-897$. [CrossRef]

22. Bigne, J.E.; Sanchez, M.I.; Sanchez, J. Tourism image, evaluation variables and after purchase behaviour: Inter-relationship. Tour. Manag. 2001, 22, 607-616. [CrossRef]

23. Lee, C.K.; Taylor, T.; Lee, Y.K.; Lee, B. The impact of a sport mega-event on destination image: The case of the 2002 FIFA World Cup Korea/Japan. Int. J. Hosp. Tour. Adm. 2005, 6, 27-45. [CrossRef]

24. McDowall, S.; Ma, E. An analysis of tourists' evaluation of Bangkok's performance, their satisfaction, and destination loyalty: Comparing international versus domestic Thai tourists. J. Qual. Assur. Hosp. Tour. 2010, 11, 260-282. [CrossRef]

25. Mehrabian, A.; Russell, J.A. An Approach to Environmental Psychology; The MIT Press: Cambridge, MA, USA, 1974.

26. MacKinnon, D.P.; Fairchild, A.J.; Fritz, M.S. Mediation analysis. Annu. Rev. Psychol. 2007, 58, 593-614. [CrossRef]

27. Su, L.; Hsu, M.K. Service fairness, consumption emotions, satisfaction, and behavioral intentions: The experience of Chinese heritage tourists. J. Travel Tour. Mark. 2013, 30, 786-805. [CrossRef]

28. Gallarza, M.G.; Saura, I.G.; García, H.C. Destination image: Towards a conceptual framework. Ann. Tour. Res. 2002, 29, 56-78. [CrossRef]

29. Hunt, J.D. Image: A Aspect in Tourism. Ph.D. Thesis, Colorado State University, Fort Collins, CO, USA, 1971.

30. Crompton, J.L. An assessment of the image of Mexico as a vacation destination and the influence of geographical location upon that image. J. Travel Res. 1979, 17, 18-23. [CrossRef]

31. Kim, H.; Richardson, S.L. Motion picture impacts on destination images. Ann. Tour. Res. 2003, 30, $216-237$. [CrossRef]

32. Sahin, S.; Baloglu, S. Brand personality and destination image of Istanbul. Anatolia Int. J. Tour. Hosp. Res. 2011, 22, 69-88. [CrossRef]

33. Echtner, C.M.; Ritchie, J.R. The Measurement of Destination Image: An Empirical Assessment. J. Tour. Stud. 1993, 31, 3-13. [CrossRef]

34. Echtner, C.M.; Ritchie, J.R. The meaning and measurement of destination image. J. Tour. Stud. 1991, 2, 2-12.

35. Stepchenkova, S.; Mills, J.E. Destination image: A meta-analysis of 2000-2007 research. J. Hosp. Mark. Manag. 2010, 19, 575-609. [CrossRef]

36. Zhang, H.; Fu, X.; Cai, L.A.; Lu, L. Destination image and tourist loyalty: A meta-analysis. Tour. Manag. 2014, 40, 213-223. [CrossRef]

37. Truong, T.H.; King, B. An evaluation of satisfaction levels among Chinese tourists in Vietnam. Int. J. Tour. Res. 2009, 11, 521-535. [CrossRef]

38. Boulding, K.E. General systems theory-The skeleton of science. Manag. Sci. 1956, 2, 197-208. [CrossRef]

39. Chun, Y. Minimal cooperation in bargaining. Econ. Lett. 1990, 34, 311-316. [CrossRef]

40. Guthrie, J.; Gale, P. Positioning ski areas. In New Horizons Conference Proceedings; University of Calgary: Calgary, AB, Canada, 1991.

41. Hunt, J.D. Image as a Aspect in Tourism Development. J. Travel Res. 1975, 13, 1-7. [CrossRef]

42. Hosany, S.; Ekinci, Y.; Uysal, M. Destination image and destination personality: An application of branding theories to tourism places. J. Bus. Res. 2006, 59, 638-642. [CrossRef]

43. Hahm, J.; Wang, Y. Film-induced tourism as a vehicle for destination marketing: Is it worth the efforts? J. Travel Tour. Mark. 2011, 28, 165-179. [CrossRef]

44. Kim, W.; Malek, K. Effects of self-congruity and destination image on destination loyalty: The role of cultural differences. Anatolia 2017, 28, 1-13. [CrossRef]

45. Qu, H.; Kim, L.H.; Im, H.H. A model of destination branding: Integrating the concepts of the branding and destination image. Tour. Manag. 2011, 32, 465-476. [CrossRef]

46. Almeida-Santana, A.; Moreno-Gil, S. Understanding tourism loyalty: Horizontal vs. destination loyalty. Tour. Manag. 2018, 65, 245-255. [CrossRef] 
47. Beerli, A.; Martin, J.D. Aspects influencing destination image. Ann. Tour. Res. 2004, 31, 657-681. [CrossRef]

48. Lin, C.H.; Morais, D.B.; Kerstetter, D.L.; Hou, J.S. Examining the role of cognitive and affective image in predicting choice across natural, developed, and theme-park destinations. J. Travel Res. 2007, 46, 183-194. [CrossRef]

49. Li, M.; Cai, L.A.; Lehto, X.Y.; Huang, J. A missing link in understanding revisit intention-The role of motivation and image. J. Travel Tour. Mark. 2010, 27, 335-348. [CrossRef]

50. Wang, C.Y.; Hsu, M.K. The relationships of destination image, satisfaction, and behavioral intentions: An integrated model. J. Travel Tour. Mark. 2010, 27, 829-843. [CrossRef]

51. Stylidis, D.; Shani, A.; Belhassen, Y. Testing an integrated destination image model across residents and tourists. Tour. Manag. 2017, 58, 184-195. [CrossRef]

52. Backman, S.J.; Crompton, J.L. The usefulness of selected variables for predicting activity loyalty. Leis. Sci. 1991, 13, 205-220. [CrossRef]

53. Baloglu, S. An investigation of a loyalty typology and the multidestination loyalty of international travelers. Tour. Anal. 2001, 6, 41-52. [CrossRef]

54. Yoon, Y.; Uysal, M. An examination of the effects of motivation and satisfaction on destination loyalty: A structural model. Tour. Manag. 2005, 26, 45-56. [CrossRef]

55. Jacoby, J.; Chestnut, R.W. Brand Loyalty: Measurement and Management, 1st ed.; John Wiley \& Sons Inc.: New York, NY, USA, 1978; ISBN 100471028452.

56. Chew, E.Y.T.; Jahari, S.A. Destination image as a mediator between perceived risks and revisit intention: A case of post-disaster Japan. Tour. Manag. 2014, 40, 382-393. [CrossRef]

57. Yu, L.; Goulden, M. A comparative analysis of international tourists' satisfaction in Mongolia. Tour. Manag. 2006, 27, 1331-1342. [CrossRef]

58. Bowen, D.; Clarke, J. Reflections on tourist satisfaction research: Past, present and future. J. Vacat. Mark. 2002, 8, 297-308. [CrossRef]

59. Turner, L.W.; Reisinger, Y.V.; McQuilken, L. How cultural differences cause dimensions of tourism satisfaction. J. Travel Tour. Mark. 2002, 11, 79-101. [CrossRef]

60. Özdemir, C.; Yolal, M. Cross-cultural tourist behavior: An examination of tourists' behavior in guided tours. Tour. Hosp. Res. 2017, 17, 314-324. [CrossRef]

61. Kozak, M. Repeaters' behavior at two distinct destinations. Ann. Tour. Res. 2001, 28, 784-807. [CrossRef]

62. Crotts, J.C.; Erdmann, R. Does national culture influence consumers' evaluation of travel services? A test of Hofstede's model of cross-cultural differences. Manag. Serv. Qual. Int. J. 2000, 10, 410-419. [CrossRef]

63. Pizam, A.; Sussmann, S. Does nationality affect tourist behavior? Ann. Tour. Res. 1995, 22, 901-917. [CrossRef]

64. Mattila, A.S. The impact of culture and gender on customer evaluations of service encounters. J. Hosp. Tour. Res. 2000, 24, 263-273. [CrossRef]

65. You, X.; O'leary, J.; Morrison, A.; Hong, G.S. A cross-cultural comparison of travel push and pull factors: United Kingdom vs. Japan. Int. J. Hosp. Tour. Adm. 2000, 1, 1-26. [CrossRef]

66. Levy, S.E. The hospitality of the host: A cross-cultural examination of managerially facilitated consumer-to-consumer interactions. Int. J. Hosp. Manag. 2010, 29, 319-327. [CrossRef]

67. Tsang, N.K.F.; Ap, J. Tourists' perceptions of relational quality service attributes: A cross-cultural study. J. Travel Res. 2007, 45, 355-363. [CrossRef]

68. Choi, T.Y.; Chu, R. Levels of satisfaction among Asian and Western travellers. Int. J. Qual. Reliab. Manag. 2000, 17, 116-132. [CrossRef]

69. Bauer, T.; Jago, L.; Wise, B. The changing demand for hotel facilities in the Asia Pacific region. Int. J. Hosp. Manag. 1993, 12, 313-322. [CrossRef]

70. Matzler, K.; Strobl, A.; Stokburger-Sauer, N.; Bobovnicky, A.; Bauer, F. Brand personality and culture: The role of cultural differences on the impact of brand personality perceptions on tourists' visit intentions. Tour. Manag. 2016, 52, 507-520. [CrossRef]

71. Williams, P.; Soutar, G.; Ashill, N.J.; Naumann, E. Value drivers and adventure tourism: A comparative analysis of Japanese and Western consumers. J. Serv. Theory Pract. 2017, 27, 102-122. [CrossRef]

72. MacKay, K.J.; Fesenmaier, D.R. An exploration of cross-cultural destination image assessment. J. Travel Res. 2000, 38, 417-423. [CrossRef]

73. Carroll, A.B. The pyramid of corporate social responsibility: Toward the moral management of organizational stakeholders. Bus. Horiz. 1991, 34, 39-48. [CrossRef] 
74. Dahlsrud, A. How corporate social responsibility is defined: An analysis of 37 definitions. Corp. Soc. Responsib. Environ. Manag. 2008, 15, 1-13. [CrossRef]

75. Fatma, M.; Rahman, Z.; Khan, I. Measuring consumer perception of CSR in tourism industry: Scale development and validation. J. Hosp. Tour. Manag. 2016, 27, 39-48. [CrossRef]

76. Kim, J.S.; Song, H.; Lee, C.K.; Lee, J.Y. The impact of four CSR dimensions on a gaming company's image and customers' revisit intentions. Int. J. Hosp. Manag. 2017, 61, 73-81. [CrossRef]

77. Ma, B.; Su, L.; Ding, Y.; Hu, X. Understanding the relationships among destination social responsibility, resident benefits, trust and support for tourism development. Inf. Technol. J. 2013, 12, 5947-5954. [CrossRef]

78. Martín-Santana, J.D.; Beerli-Palacio, A.; Nazzareno, P.A. Antecedents and consequences of destination image gap. Ann. Tour. Res. 2017, 62, 13-25. [CrossRef]

79. Chen, C.C. Examining Stress Relief Benefits of Tourism Experiences: A Study of American Workers. Tour. Anal. 2018, 23, 421-426. [CrossRef]

80. Tamajón, L.G.; Font, X. Corporate social responsibility in tourism small and medium enterprises evidence from Europe and Latin America. Tour. Manag. Perspect. 2013, 7, 38-46. [CrossRef]

81. Jang, Y.Y. A Study on the Effects of Hotel Businesses' Perceived Corporate Social Responsibility Activities on Their Corporate Image, Customer Satisfaction and Behavioural Intention. Ph.D. Thesis, Kyung Hee University, Seoul, Korea, 2017.

82. Martínez, P.; Pérez, A.; Rodríguez del Bosque, I. Measuring corporate social responsibility in tourism: Development and validation of an efficient measurement scale in the hospitality industry. J. Travel Tour. Mark. 2013, 30, 365-385. [CrossRef]

83. Kang, B.J.; Kim, I.I.; Hyun, S.H. The effect of corporate social responsibility on customers' brand identification and customer citizenship Behaviour in hotel industry. Int. J. Tour. Manag. Sci. 2016, 31, 191-208.

84. Astrachan, C.B.; Patel, V.K.; Wanzenried, G. A comparative study of CB-SEM and PLS-SEM for theory development in family firm research. J. Fam. Bus. Strategy 2014, 5, 116-128. [CrossRef]

85. Haenlein, M.; Kaplan, A.M. A beginner's guide to partial least squares analysis. Underst. Stat. 2004, 3, 283-297. [CrossRef]

86. Hair, J.F.; Sarstedt, M.; Hopkins, L.G.; Kuppelwieser, V. Partial least squares structural equation modeling (PLS-SEM) An emerging tool in business research. Eur. Bus. Rev. 2014, 26, 106-121. [CrossRef]

87. Do Valle, P.O.; Assaker, G. Using partial least squares structural equation modeling in tourism research: A review of past research and recommendations for future applications. J. Travel Res. 2016, 55, 695-708. [CrossRef]

88. Ali, F.; Rasoolimanesh, S.M.; Sarstedt, M.; Ringle, C.M.; Ryu, K. An assessment of the use of partial least squares structural equation modeling (PLS-SEM) in hospitality research. Int. J. Contemp. Hosp. Manag. 2018, 30, 514-538. [CrossRef]

89. Chin, W.W. How to write up and report PLS analyses. In Handbook of Partial Least Squares, 1st ed.; Vinzi, V.E., Chin, W.W., Henseler, J., Wang, H., Eds.; Springer: Berlin, Germanay, 2010; pp. 655-690. ISBN 978-3-540-32825-4.

90. Hoi An Centre for Monuments Managements and Preservation. IMPACT: The Effects of Tourism on Culture and the Environment in Asia and the Pacific: Cultural Tourism and Heritage Management in the World Heritage Site of the Ancient Town of Hoi An; UNESCO Bangkok: Bangkok, Thailand, 2008; ISBN 978-92-9223-222-1.

91. Adongo, R.; Choe, J.Y.; Han, H. Tourism in Hoi An, Vietnam: Impacts, perceived benefits, community attachment and support for tourism development. Int. J. Tour. Sci. 2017, 17, 86-106. [CrossRef]

92. Hair, J.F.; Ringle, C.M.; Sarstedt, M. PLS-SEM: Indeed a silver bullet. J. Mark. Theory Pract. 2011, 19, $139-152$. [CrossRef]

93. Falk, R.F.; Miller, N.B. A Primer for Soft Modeling, 1st ed.; University of Akron Press: Akron, OH, USA, 1992; ISBN 100962262846.

94. Sirgy, M.J. Self-concept in consumer behavior: A critical review. J. Consum. Res. 1982, 9, 287-300. [CrossRef]

95. Sirgy, M.J.; Su, C. Destination image, self-congruity, and travel behavior: Toward an integrative model. J. Travel Res. 2000, 38, 340-352. [CrossRef]

(C) 2019 by the authors. Licensee MDPI, Basel, Switzerland. This article is an open access article distributed under the terms and conditions of the Creative Commons Attribution (CC BY) license (http:/ / creativecommons.org/licenses/by/4.0/). 